\title{
Assessment of in vitro and in vivo Antimicrobial Activity of an Isonitrosomalononitrile Silver(I) Salt
}

\author{
Marie Colmont ${ }^{1}$ and Jean Michel Brunel ${ }^{2, *}$ \\ ${ }^{1}$ Université Lille, CNRS, Centrale Lille, Université Artois, UMR, Unité de Catalyse et Chimie du Solide, Lille, France \\ ${ }^{2}$ Aix-Marseille University, INSERM, SSA, MCT, Marseille, France
}

*Corresponding author: Jean Michel Brunel, Aix-Marseille University, INSERM, SSA, MCT, Marseille, France, E-mail: bruneljm@yahoo.fr

Received: 31 May, 2021 | Accepted: 30 Jun, 2021 | Published: 15 Jul, 2021

Citation: Colmont M, Brunel JM (2021) Assessment of in vitro and in vivo Antimicrobial Activity of an Isonitrosomalononitrile Silver(I) Salt. J Med Chem Drug Des 3(1): dx.doi.org/10.16966/2578-9589.117

Copyright: (C) 2021 Colmont M, et al. This is an open-access article distributed under the terms of the Creative Commons Attribution License, which permits unrestricted use, distribution, and reproduction in any medium, provided the original author and source are credited.

\begin{abstract}
The design and evaluation of antimicrobial activities of an isonitrosomalononitrile silver(I) salt was reported. This highly stable water-soluble silver salt shows Minimum Inhibitory Concentrations (MIC) values ranging from 0.15 to $5 \mu \mathrm{g} / \mathrm{mL}$ towards both sensitive and resistant Gram-positive and negative bacteria. Furthermore, this silver salt has been investigated for its ability to treat a $S$. aureus infected Galleria mellonella larvae animal model with promising results. Thus, our results demonstrated that $80 \%$ of the treated larvae survived after $24 \mathrm{~h}$ with respect to $10 \%$ of the untreated ones, respectively.
\end{abstract}

Keywords: Antimicrobial drug; Isonitrosomalononitrile silver complex; Galleria mellonella; Staphylococcus aureus

\section{Introduction}

Extensive misuse of antibiotics world wide lead to the emergence of antimicrobial resistance as a major threat to healthcare [1]. Thus, numerous scientists reported the end of the antibiotic age [2-4] and the emergence of multidrug-resistant bacteria (superbugs) such as vancomycin-resistant Enterococcus (VRE), Staphylococcus aureus (MRSA) and Pseudomonas aeruginosa (MRPA) [5-6]. Furthermore, the development of novel resistance should therefore be a prime activity of research in industry [7]. In this context, silver-based drugs [8-13] constitute an interesting area of research since one of their possible mechanism of action in vivo could be denaturing the deoxyribonucleic acid (DNA) molecule by disrupting the hydrogen bonding between the two anti-parallel strands [14]. Indeed, the antimicrobial activity of silver by limiting the growth of bacteria and biofilms [15] is well established [16] and its use applied into many medical products (e.g. catheters, plasters).

Thus, it has been suggested that such a class of derivatives such as carbene-silver acetates could be of interest to become drug candidates [17-18]. Furthermore, the development of more lipophilic benzimidazole-derived carbene-silver complexes presenting potent activities against numerous bacteria were recently reported [1920]. This paper describes the synthesis and biological antimicrobial evaluation of a new isonitrosomalononitrile silver salt against both Gram-positive and negative bacteria and demonstrates its in vivo efficiency against a $S$. aureus infected G. mellonella larvae animal model.

\section{Results and Discussion}

The preparation of the isonitrosomalononitrile silver(I) salt 4 was easily achieved in a two steps synthesis as outlined in scheme 1. A solution of malononitrile1 in acetic acid reacted with an aqueous solution of sodium nitrite to lead to the formation of the expected isonitrosomalononitrile 2. This latter can subsequently react with an aqueous solution of silver nitrate to afford the expected isonitrosomalononitrile silver(I) salt 4 as a stable yellow solid in $91 \%$ yield ( ${ }^{13} \mathrm{C}$ NMR (63 MHz, CD $\left.\mathrm{OD}\right) \delta$ (ppm): 118.44, 112.50, 107.39). In parallel, we prepared the corresponding isonitrosomalononitrile potassium salt 3 parent derivatives to compare the influence of the nature of the metal used on the potent antimicrobial activities encountered. In this case, the isonitrosomalononitrile potassium salt was prepared by mixing as previously a solution of sodium nitrite solution in acetic acid in the presence of malononitrile 1 for $1 \mathrm{~h}$ then quenched by adding $2 \mathrm{~N}$ hydrochloric acid solution. After extraction, the oily residue can be purified by flash chromatography to afford isonitrosomalononitrile 2 in $83 \%$ yield or treated by a potassium hydroxide solution to lead to the expected isonitrosomalononitrile potassium salt 3 as yellow powder in $86 \%$ yield. This powder can be crystalized by slow cooling of an oversaturated water solution heated at $50^{\circ} \mathrm{C}$. These affordedlarge crystals suitable for X-ray structure analysis. 


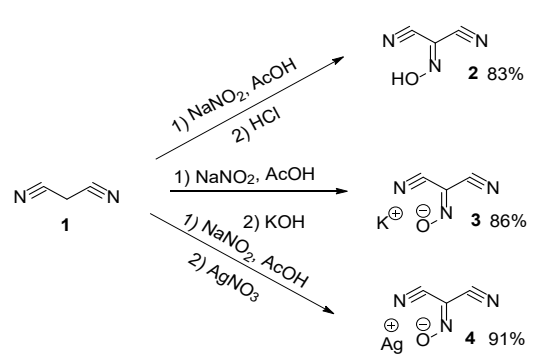

A suitable yellow single crystal of 3 was carefully selected under a polarizing microscope and deposited on a single loop for single crystal $\mathrm{X}$-ray diffraction analysis (Figure 1).

Atoms are drawn with their respective thermal ellipsoids. A photograph of crystals of 3 is shown in insert. The data were collected on a Bruker X8 APEX2 diffractometer using an Incoatec Ag-Ka Microfocus source $(\lambda=0.56086 \AA)$ at room temperature. The diffraction intensities were collected until $2 \theta=36.36^{\circ}$. This value is related to the absence of reflections at high angles which is linked to the crystallinity of the crystals. The intensities were extracted from the frames using SAINT V7 53a (SAINT: Area-Detector Integration Software. Madison: Siemens Industrial Automation, Inc., 1996). A monoclinic unit cell a $=8.7459$ (4), $b=8.8229$ (3), $c=7.1182$ (3) and $\beta=106.23$ (1) was deduced from all data set. Intensities were semi-empirically corrected from absorption effects using SADABS (SADABS: Area-Detector Absorption Correction. Madison: Siemens Industrial Automation, Inc., 1995). The observed systematic extinction conditions led to use the space group $\mathrm{P} 2 / \mathrm{c}$. The crystal structure was determined by using the software SUPERFLIP [21] and further refined by full-matrix leastsquares procedures using JANA2006 software [22]. At the end of the refinement, the final $\mathrm{R}$ value was 0.0253 , obtained for 759 reflections $(\mathrm{I}>3 \sigma(\mathrm{I}))$. All experimental conditions as well as structure refinement details are given in table 1 .

In the obtain structure, there is one independent crystallographic site for potassium and oxygen and three for both carbon and nitrogen. The atomic coordinates, isotropic and anisotropic displacement parameters are listed in table 2.

The lengthening of bond lengths is of 1.136 (4), 1.139 (3) and 1.322 (3) Å for respectively N1-C1, N2-C2 and N3-C3 which correspond perfectly with double and triple $\mathrm{C}-\mathrm{N}$ bonds. Concerning single $\mathrm{C}-\mathrm{C}$ distances, there are at 1.426 (4) and 1.425 (3) $\AA$ for C1-C3 and C2C3 in good agreement with expected bond lengths. N3-O1 bond distance is at 1.286(2) $\AA$ corresponding to usual N-O distances [23] since isonitrosomalononitrile molecule is almost planar. C1-C3-N3 angle of $122.0(2)^{\circ}$ and $\mathrm{C} 1-\mathrm{C} 3-\mathrm{C} 2$ of $119.5(2)^{\circ}$. N1-C1-C3 is almost linear $\left(177.1(3)^{\circ}\right)$ as expected in case of $\mathrm{C}-\mathrm{C}=\mathrm{C}$ bond. O1-N3-C3 is at $115.8(2)^{\circ}$ which is a little bit further than common $120^{\circ}$. The potassium is coordinated by eight atoms, five azote and three oxygen with distances ranging from 2.811 (2) to 3.022(3) $\AA$. The potassium is capping the molecule from (O1) and nitrogen (N1, N2 and N3). The main distances are gathered in table 3 .

The X-ray diffraction analysis of the synthesized powder of 3 confirmed the correlation with the determined crystal structure of isonitrosomalononitrile potassium salt 3 and the purity of the sample. A Pattern matching performed using the same space group and unit cell parameters shows the perfect matching between both (Figure 2).

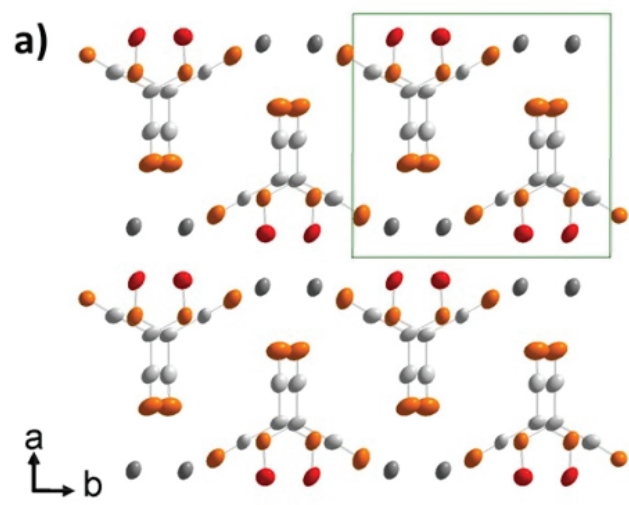

c)

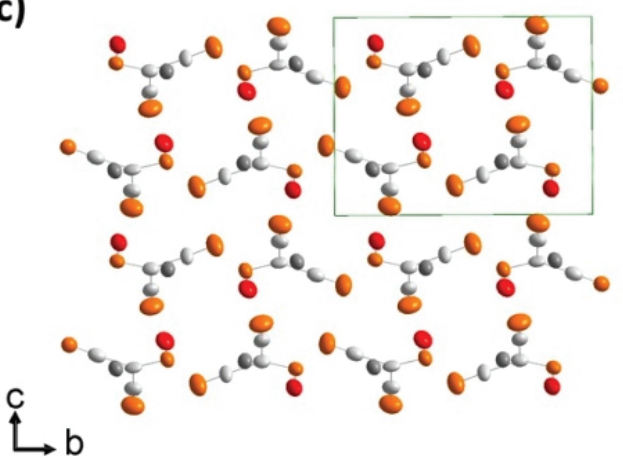

b)

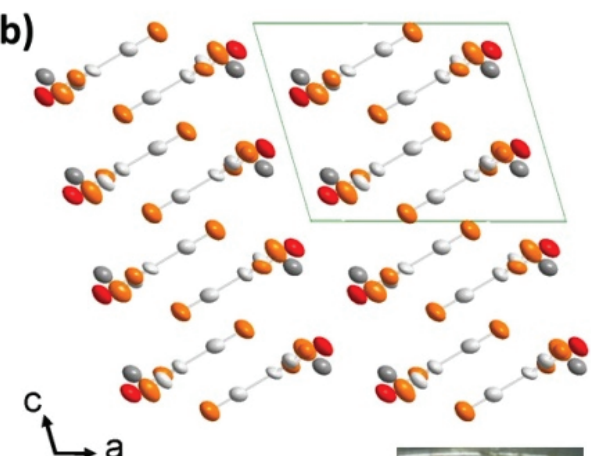

d)

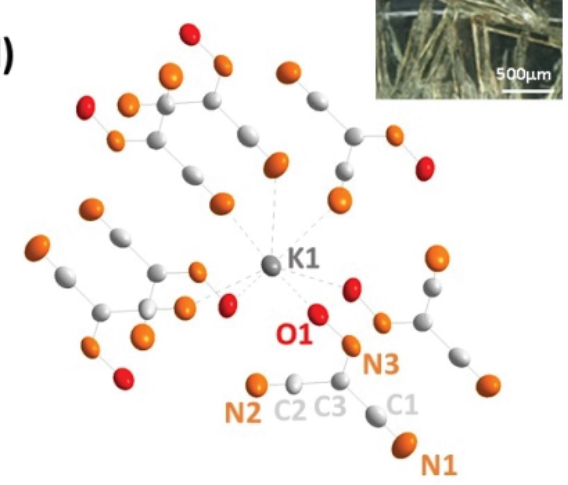

Figure 1: Crystal structure of isonitrosomalononitrile potassium salt presented along a) c, b) b, and c) a-axis and d) molecular structure of 3 with presentation of atom labelling scheme. 
Table 1: Crystal data and structure refinement details for 3.

\begin{tabular}{|c|c|}
\hline CCD Number & 2004760 \\
\hline Formula & K1C3N3O \\
\hline Formula weight (g/mol) & 133.2 \\
\hline Temperature (K) & 300 \\
\hline Wavelength (Å) & 0.56086, (Silver microsource) \\
\hline Crystal system & Monoclinic \\
\hline Space group & $\mathrm{P} 2_{1} / \mathrm{c}\left(\mathrm{n}^{\circ} 14\right)$ \\
\hline$a, b, c,(\AA), \beta\left({ }^{\circ}\right)$ & $\begin{array}{l}8.7459(4), 8.8229(3), 7.1182(3), \\
106.23(1)\end{array}$ \\
\hline Volume $\left(\AA^{3}\right)$ & $527.39(26)$ \\
\hline $\mathbf{Z}$ & 4 \\
\hline Calculated density, $\left(\mathrm{g} / \mathrm{cm}^{3}\right)$ & 1.6775 \\
\hline Crystal size $\left(\mathrm{mm}^{3}\right)$ & $0.50 * 0.19 * 0.21$ \\
\hline$\Theta$ range for data collection $\left({ }^{\circ}\right)$ & $1.91-18.18$ \\
\hline Limiting indices & $-8 \leq h \leq 8,-8 \leq k \leq 8,-7 \leq 1 \leq 7$ \\
\hline Reflections collected/unique & $16460 / 759$ [Rint $=0.1298]$ \\
\hline Data/restraints/parameters & $759 / 0 / 74$ \\
\hline GOOF on I & 1.00 \\
\hline Final $R$ indices $R[1>3 \sigma(I)]$ & $\mathrm{R}_{\mathrm{all}}=0.0253, \mathrm{wR}_{\mathrm{all}}=0.0319$ \\
\hline Final $R$ indices for all data & $\mathrm{R}_{\mathrm{all}}=0.0405, \mathrm{wR}_{\mathrm{all}}=0.0351$ \\
\hline
\end{tabular}

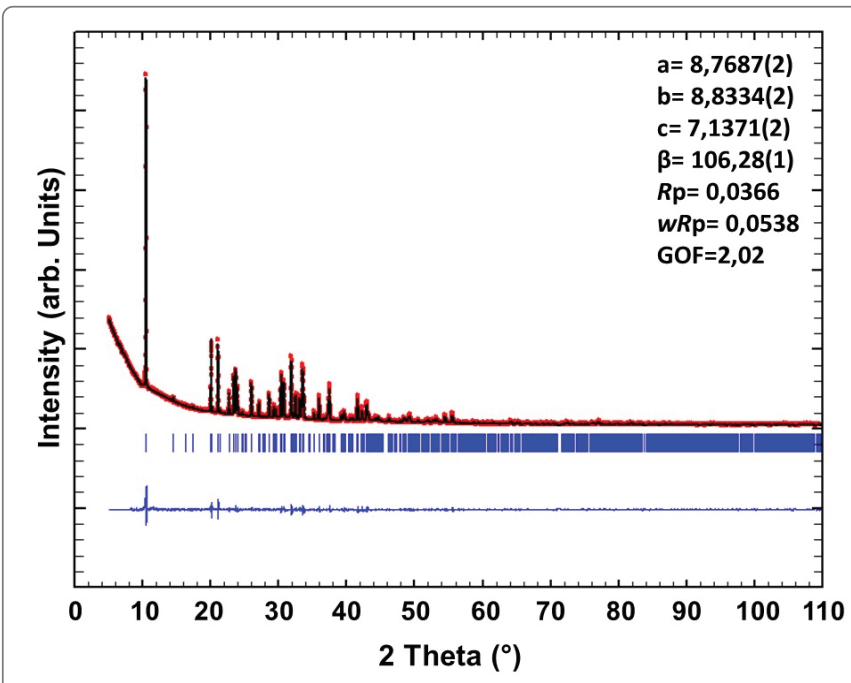

Figure 2: Pattern matching profile of powder X-ray diffraction pattern of isonitrosomalononitrile potassium salt 3.

Now, despite all our attempts, we were unable to obtain crystals corresponding to the powder of isonitrosomalononitrile silver salt 4 suitable for X-ray analysis. The X-ray powder diffraction pattern is also different from the one of isonitrosomalononitrile potassium salt 3 which implies that the isonitrosomalononitrile silver salt 4 is differently arranged, in strong relation with the rather big different size of the respective ionic radii.
The crystals obtained were nevertheless studied by X-ray diffraction. Their analysis shows a monoclinic unit cell with parameters $\mathrm{a}=17.315(4)$ $\AA, b=3.598$ (1) $\AA, c=17.316$ (4) $\AA$ and $\beta=110.34(1)^{\circ}$, S.G. P2 ${ }_{1}$. The poor quality of the crystals only allowed to propose a hypothetical model of that unknown phase presented on figure 3 which confirmed the differences with the expected the isonitrosomalononitrile silver salt 4 .

All the synthesized water-soluble compounds were then screened for their potent antimicrobial activity against sensitive or resistant Gram-positive and negative bacteria strains as listed in table 4 .

First, we must notice that isonitrosomalononitrile 2 and isonitrosomalononitrile potassium salt 3 do not possess any activity even at high concentrations against the tested bacterial strains. Nevertheless, isonitrosomalononitrile silver salt 4 was found to be active against all the microorganisms tested with Minimum Inhibitory Concentrations (MICs) varying from 0.625 to $2.5 \mu \mathrm{g} / \mathrm{mL}$ whatever the considered bacterial strains. Thus, 4 is active in the same range against Gram-positive and negative bacteria and in no case, we have noticed a lack of activity. Thus, the great difference in terms of antimicrobial efficiency between the different tested compounds 1-4 seems to be exclusively related to the presence of a silver atom in the case of derivative 4 . Indeed, the absence or replacement of this atom by a potassium atom leads to a loss of activity of the considered compound. Otherwise, since the MICs encountered are very close whatever the considered Gram-negative or Gram-positive bacteria as well as sensitive or resistant it is reasonable to envision that 4 possess a common mechanism of action against these pathogens. Furthermore, similar MICs were observed when targeting MDR bacteria or sensitive ones such as P. aeruginosa and PA01 as well as S. aureus ATCC25923and CF Marseille. All these considerations could indicate that 4 possess a mechanism of action which circumvents the mechanisms of resistance involved by the bacteria towards conventional antibiotics.

The cytotoxic activity of isonitrosomalononitrile silver(I) salt 4 was also assessed by investigating the cell viability. Thus, two different physiological mechanisms involving the ability of mitochondrial dehydrogenases to transform WST-1 to formazan as well as the lysosomal membranes capacity to concentrate Neutral Red. All the results indicated that isonitrosomalononitrile silver(I) salt 4 has a moderate cytotoxicity with an $\mathrm{IC}_{50}$ around $35 \mu \mathrm{M}$ with respect to requested concentration necessary against all the bacteria tested. On the other hand, no differences are observed in the $\mathrm{IC}_{50}$ values regarding the nature of the cell line, or the vital dye considered suggesting a global impact on different intracellular targets (Table 5). Moreover, $\mathrm{IC}_{50}$ 's in the same range than those obtained for well-known $\mathrm{AgNO}_{3}$ were encountered opening the way for animal testing's.

Due to their ability to possess an immune system similar to mammals [24] cheap Greater Wax Moth, Galleria mellonella [25-26] were widely chosen to evaluate the in vivo efficacy and stability of new antimicrobial compounds and determine the virulence of microbial pathogens [27] in 24-48 h [28-29]. A preliminary study was performed by using Galleria mellonella larvae as an animal model to determine their tolerance to isonitrosomalononitrile silver salt 4 as well as its in vivo activity against a $S$. aureus infection. Thus, no toxicity up to a concentration of $25 \mu \mathrm{g} / \mathrm{mL}(12 \mu \mathrm{M})$ was encountered whereas larvae inoculated with a dose of $50 \mu \mathrm{g} / \mathrm{mL}$ showed a $90 \%$ reduction in viability after $24 \mathrm{~h}$. Finally, larvae inoculated with isonitrosomalononitrile silver salt $4(3.125,6.25,12.5,25 \mu \mathrm{g} / \mathrm{mL})$ do not present any signs of acute toxicity such cuticular darkening (Figure 4A).

Toensuretothepreliminary in vivoactivityofisonitrosomalononitrile silver salt 4, larvae were infected with S. aureus ATCC25923 $(20 \mu \mathrm{L}$ of a 
Table 2: Atomic positions, isotropic and anisotropic displacement parameters $\left(\AA^{3}\right)$ for 3 .

\begin{tabular}{|c|c|c|c|c|c|c|}
\hline Atom & \multicolumn{2}{|c|}{$x$} & $\mathbf{Y}$ & \multicolumn{2}{|c|}{$\mathbf{Z}$} & Ueq \\
\hline K1 & \multicolumn{2}{|c|}{$0.62374(6)$} & $0.85209(6)$ & \multicolumn{2}{|c|}{$0.23261(8)$} & $0.0353(2)$ \\
\hline 01 & \multicolumn{2}{|c|}{$0.5958(2)$} & $0.1605(2)$ & \multicolumn{2}{|c|}{$0.1294(3)$} & $0.0432(7)$ \\
\hline C1 & \multicolumn{2}{|c|}{$0.7397(3)$} & $0.4258(3)$ & \multicolumn{2}{|c|}{$0.1995(3)$} & $0.0341(9)$ \\
\hline C2 & \multicolumn{2}{|c|}{$0.9826(3)$} & $0.2861(3)$ & \multicolumn{2}{|c|}{$0.3701(4)$} & $0.0361(10)$ \\
\hline C3 & \multicolumn{2}{|c|}{$0.8185(3)$} & $0.2857(3)$ & \multicolumn{2}{|c|}{$0.2627(3)$} & $0.0298(9)$ \\
\hline N1 & \multicolumn{2}{|c|}{$0.6708(3)$} & $0.5342(3)$ & \multicolumn{2}{|c|}{$0.1472(4)$} & $0.0547(10)$ \\
\hline N2 & \multicolumn{2}{|c|}{$0.1137(3)$} & $0.2870(3)$ & \multicolumn{2}{|c|}{$0.4561(3)$} & $0.0542(11)$ \\
\hline N3 & \multicolumn{2}{|c|}{$0.7443(2)$} & $0.1540(2)$ & \multicolumn{2}{|c|}{$0.2242(3)$} & $0.0365(8)$ \\
\hline Atom & U11 & U22 & U33 & U12 & U13 & U23 \\
\hline K1 & $0.0335(4)$ & $0.0271(4)$ & $0.0411(4)$ & $0.0003(2)$ & $0.0035(2)$ & $0.0012(3)$ \\
\hline 01 & $0.0362(11)$ & $0.0360(12)$ & $0.0490(11)$ & $-0.0052(8)$ & $-0.0020(9)$ & $-0.0003(8)$ \\
\hline C1 & $0.0274(13)$ & $0.0300(17)$ & $0.0425(15)$ & $-0.0084(13)$ & $0.0059(12)$ & $-0.0024(12)$ \\
\hline $\mathrm{C} 2$ & $0.0344(16)$ & $0.0417(18)$ & $0.0316(14)$ & $0.0048(12)$ & $0.0084(12)$ & $-0.0005(12)$ \\
\hline C3 & $0.0276(13)$ & $0.0286(16)$ & $0.0301(13)$ & $0.0009(11)$ & $0.0031(11)$ & $0.0020(10)$ \\
\hline N1 & $0.0432(14)$ & $0.0336(17)$ & $0.0774(17)$ & $0.0000(12)$ & $0.0004(12)$ & $0.0030(13)$ \\
\hline N2 & $0.0355(15)$ & $0.067(2)$ & $0.0531(16)$ & $0.0047(12)$ & $0.0015(12)$ & $-0.0046(13)$ \\
\hline N3 & $0.0364(12)$ & $0.0308(14)$ & $0.0395(12)$ & $0.0030(10)$ & $0.0057(10)$ & $0.0013(10)$ \\
\hline
\end{tabular}

Table 3: Main bond distances and length in crystal of 3.

\begin{tabular}{|c|c|c|c|}
\hline Atoms & Bond distance $(\AA \mathbf{A})$ & Atoms & Bond angle $\left(^{\circ}\right)$ \\
\hline N1-C1 & $1.136(4)$ & & $120.9(2)$ \\
N1-K1 & $2.924(3)$ & C1-N1-K1 & $122.6(2)$ \\
O1-K1 & $2.752(2)$ & C2-N2-K1 & $177.1(3)$ \\
N2-C2 & $1.139(3)$ & N1-C1-C3 & $179.7(3)$ \\
N2-K1 & $2.974(2)$ & N2-C2-C3 & $119.5(2)$ \\
C1-C3 & $1.426(4)$ & C1-C3-C2 & $122.0(2)$ \\
C2-C3 & $1.425(3)$ & C1-C3-N3 & $118.4(2)$ \\
N3-K1 & $2.872(2)$ & C2-C3-N3 & \\
N3-C3 & $1.322(3)$ & & \\
\hline
\end{tabular}

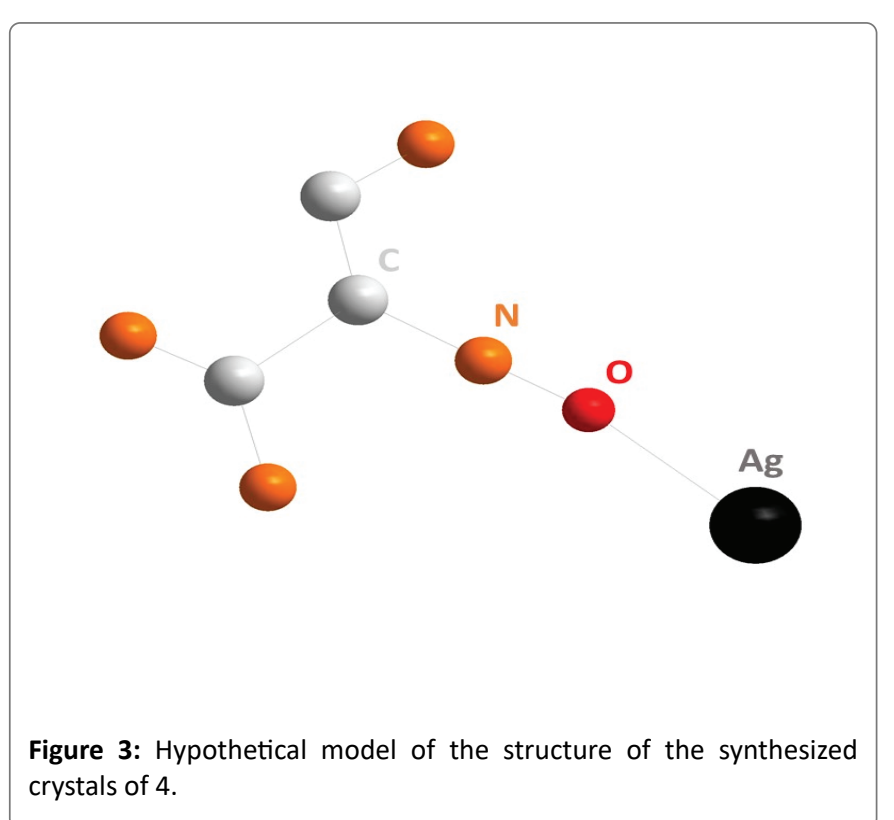

solution containing $10^{7}$ bacterial cells) and subsequently administered with or without isonitrosomalononitrile silver salt $4(6.25 \mu \mathrm{g} / \mathrm{mL})$ 4 h post infection. Our results demonstrated that $80 \%$ of the treated larvae survived after $24 \mathrm{~h}$ with respect to $10 \%$ of the untreated ones, respectively (Figure $4 \mathrm{~B}$ ). These preliminary but promising data open the way to perform more detailed studies typically for atopical use towards $S$. aureus Skin infections.

\section{Conclusion}

The design and evaluation of antimicrobial activities of a watersoluble isonitrosomalononitrile silver(I) salt with MIC values ranging from 0.15 to $5 \mu \mathrm{g} / \mathrm{mL}$ against both sensitive and resistant Gram-positive and negative bacteria was investigated. We have also demonstrated its ability to be used for the treatment of a S. aureus infected Galleria mellonella larvae animal model with promising results opening the way for a potent therapeutic use. Studies are under progress to evaluate and improve the potentiality of such silver salt derivatives as well as determine more precisely the potent mechanism of action of this new class of antimicrobial agents.

\section{Experimental Section}

All solvents were purchased from VWR and used without further purification. Reagents were used as commercially available. ${ }^{13} \mathrm{C}$ NMR spectra were recorded in $\mathrm{CDCl}_{3}$ on a Bruker AC 300 spectrometer working at $75 \mathrm{MHz}$. Tetramethylsilane was used as internal standard. All chemical shifts are given in ppm.

\section{Synthesis of isonitrosomalononitrile 2}

$7 \mathrm{~g}$ of sodium nitrite $(101 \mathrm{mmol})$ were slowly added at $0^{\circ} \mathrm{C}$ to $4 \mathrm{~g}$ of malononitrile $(65 \mathrm{mmol})$ dissolved in water $(20 \mathrm{~mL})$ and acetic acid $(10 \mathrm{~mL})$. Stirring was maintained at room temperature in the dark overnight then quenched by adding $50 \mathrm{~mL}$ of a $2 \mathrm{~N} \mathrm{HCl}$ solution. The solution was then extracted with diethyl ether and dried over $\mathrm{Na}_{2} \mathrm{SO}_{4}$. 
A

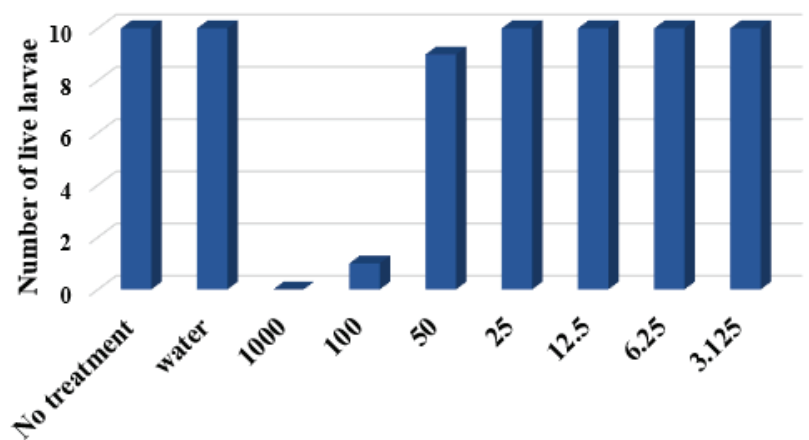

Silver salt 4 concentration used $(\mu \mathrm{g} / \mathrm{mL})$
B

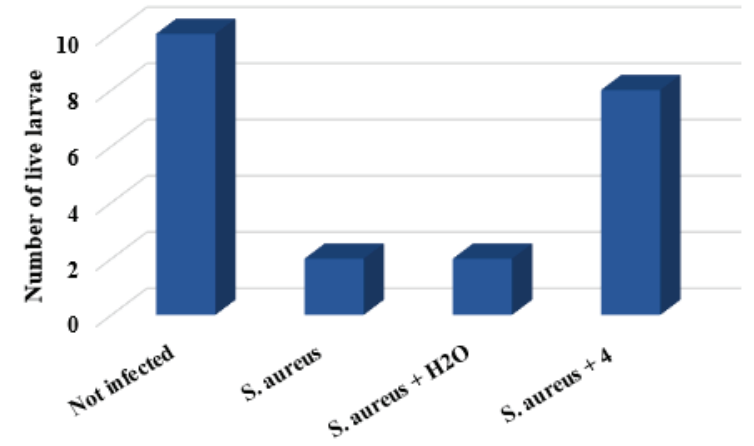

Figure 4: A) Larval survival $24 \mathrm{~h}$ after administration with water or isonitrosomalononitrile silver salt 4(3.125, 6.25, $12.5,25,50 \mu \mathrm{g} / \mathrm{mL})$. B) Survival of larvae infected with $S$. aureus ATCC25923 following administration with isonitrosomalononitrile silver salt 4 solution (6.25 $\mu \mathrm{g} / \mathrm{mL}$ ) $4 \mathrm{~h}$ after infection.

Table 4: Antibacterial activities of derivatives 2-4.

\begin{tabular}{|c|c|c|c|c|c|}
\hline \multicolumn{6}{|c|}{$\mathrm{MIC}(\mu \mathrm{g} / \mathrm{mL})$} \\
\hline & Strains & Colistin sulfate & 2 & 3 & 4 \\
\hline \multirow{7}{*}{ 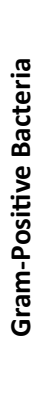 } & S. aureus CIP65.8 & $>32$ & $>256$ & $>256$ & 1.25 \\
\hline & S. aureus ATCC25923 & $>32$ & $>256$ & $>256$ & 1.25 \\
\hline & S. intermedius1051997 & $>32$ & $>256$ & $>256$ & 2.5 \\
\hline & B. cereus ATCC14579 & $>32$ & $>256$ & $>256$ & 5 \\
\hline & E. faecalis ATCC29212 & $>32$ & $>256$ & $>256$ & 5 \\
\hline & S. australis sp & $>32$ & $>256$ & $>256$ & 0.15 \\
\hline & E. coli ATCC 25922 & 16 & $>256$ & $>256$ & 2.5 \\
\hline \multirow{12}{*}{ 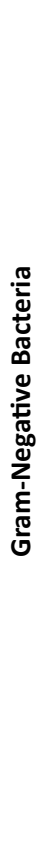 } & E. coli $0157 \mathrm{H7}$ & 16 & $>256$ & $>256$ & 1.25 \\
\hline & $\begin{array}{l}\text { E. aerogenes } \\
\text { EA289(MDR) }\end{array}$ & 16 & $>256$ & $>256$ & 5 \\
\hline & $\begin{array}{c}\text { S. } \\
\text { maltophiliaATCC51331 }\end{array}$ & 4 & $>256$ & $>256$ & 1.25 \\
\hline & $\begin{array}{l}\text { K. pneumoniae } \\
\text { NCTC13443 }\end{array}$ & 4 & $>256$ & $>256$ & 2.5 \\
\hline & K. pneumoniae ST258 & 8 & $>256$ & $>256$ & 2.5 \\
\hline & K. pneumoniae NASEY & 8 & $>256$ & $>256$ & 2.5 \\
\hline & P. aeruginosa PA01 & 2 & $>256$ & $>256$ & 2.5 \\
\hline & P. aeruginosa PA14 & 4 & $>256$ & $>256$ & 1.25 \\
\hline & $\begin{array}{l}\text { P. aeruginosa } \\
\text { ATCC27853 }\end{array}$ & 4 & $>256$ & $>256$ & 1.25 \\
\hline & P. aeruginosa PA3337 & 4 & $>256$ & $>256$ & 1.25 \\
\hline & $\begin{array}{l}\text { A. baumannii } \\
\text { ATCC17978 }\end{array}$ & 0.5 & $>256$ & $>256$ & 2.5 \\
\hline & A. baumannii AYE & 4 & $>256$ & $>256$ & 2.5 \\
\hline
\end{tabular}

After filtration, the solvents are removed under vacuum to give an oily residue which was purified by flash chromatography on silica gel using petroleum ether/ethylacetate as eluent. The product 2 is obtained as a pale-yellow oil in $83 \%$ yield.

${ }^{1} \mathrm{H}$ NMR (300 MHz, CD $\left.\mathrm{OD}\right) \delta(\mathrm{ppm}): 8.89$ (s, 1H). ${ }^{13} \mathrm{C}$ NMR $(63$ $\left.\mathrm{MHz}, \mathrm{CD}_{3} \mathrm{OD}\right) \delta$ (ppm): 113.4, 112.1, 107.1. Anal. For $\mathrm{C}_{3} \mathrm{HN}_{3} \mathrm{O}$ (95.0) Calcd: C 37.91, H 1.05, N 44.1. Found: C 37.90, H 1.15, N 43.98.MS (ESI) $\mathrm{C}_{3} \mathrm{HN}_{3} \mathrm{O} \mathrm{m} / \mathrm{z}: 96.012(100 \%,(\mathrm{M}+\mathrm{H}+))$.

\section{Synthesis of isonitrosomalononitrile potassium salt 3}

$7 \mathrm{~g}$ of sodium nitrite $(101 \mathrm{mmol})$ were slowly added at $0^{\circ} \mathrm{C}$ to $4 \mathrm{~g}$ of malononitrile $(65 \mathrm{mmol})$ dissolved in water $(20 \mathrm{~mL})$ and acetic acid $(10 \mathrm{~mL})$. Stirring was maintained at room temperature in the dark overnight then quenched by adding at $0^{\circ} \mathrm{C} 50 \mathrm{~mL}$ of a $\mathrm{KOH}(4 \mathrm{~g}, 71$ $\mathrm{mmol}$ ) methanolic solution. The reaction mixture is stirred at $0^{\circ} \mathrm{C}$ for $1 \mathrm{~h}$ then excess of diethyl ether was added to afford the potassium salt precipitation. The precipitate was collected by filtration, and then washed with diethyl ether. The yellow solid was then dried at $80^{\circ} \mathrm{C}$ under vacuum for 4 hours affording the expected compound 3 in $86 \%$ yield.

${ }^{13} \mathrm{C}$ NMR (63 MHz, CD $\left.\mathrm{OD}\right) \delta$ (ppm): 119.05, 112.93, 106.92. Anal. For $\mathrm{C}_{3} \mathrm{KN}_{3} \mathrm{O}$ (133.2) Calcd: C 27.03, N 31.53. Found: C 27.36, N 31.73.

\section{Synthesis of isonitrosomalononitrile silver salt 4}

A solution of malononitrile $(10 \mathrm{~g}, 0.15 \mathrm{~mol})$ was dissolved in 60 $\mathrm{mL}$ of acetic acid and $60 \mathrm{~mL}$ of water and cooled at $0^{\circ} \mathrm{C}$. 2. $11.5 \mathrm{~g}$ of sodium nitrite $(0.16 \mathrm{~mol})$ dissolved in $100 \mathrm{~mL}$ of water was then added drop wise. Stirring was maintained at room temperature in the dark overnight and then $100 \mathrm{~mL}$ of a water solution of silver nitrate $(23 \mathrm{~g}$, $0.15 \mathrm{~mol}$ ) was added. The precipitate was collected by filtration, and then washed with water, methanol, and diethyl ether. The yellow solid was dried at $80^{\circ} \mathrm{C}$ under vacuum for 4 hours affording the expected compound 4 in $91 \%$ yield.

${ }^{13} \mathrm{C}$ NMR (63 MHz, CD OD) $\delta$ (ppm): 118.44, 112.50, 107.39. UV (MeOH): 291 (4.06), 407 (1.90). Anal. For $\mathrm{C}_{3} \mathrm{AgN}_{3} \mathrm{O}$ (201.9) Calcd: C17.85, N 20.81. Found: C 17.46, N 20.63. 
Table 5: Cytotoxic activities of isonitrosomalononitrile silver(I) salt 4 and $\mathrm{AgNO}_{3}$

\begin{tabular}{|c|c|c|c|c|c|c|c|c|}
\hline \multirow[t]{2}{*}{ Cpd } & \multicolumn{4}{|c|}{$\mathrm{IC}_{50}(\mu \mathrm{M})$ as assessed by WST1 vital dye } & \multicolumn{4}{|c|}{$\mathrm{IC}_{50}(\mu \mathrm{M})$ as assessed by neutral red vital dye } \\
\hline & $\mathrm{CHO}$ & HEPG2 & MDCK & $3 T 3$ & $\mathrm{CHO}$ & HEPG2 & MDCK & $3 T 3$ \\
\hline 4 & $30.1 \pm 2.2$ & $31.3 \pm 2.6$ & $34.3 \pm 1.6$ & $37.4 \pm 3.8$ & $35.3 \pm 2.4$ & $39.8 \pm 3.4$ & $39.4 \pm 6.5$ & $32.6 \pm 0.8$ \\
\hline $\mathrm{AgNO}_{3}$ & $35.1 \pm 1.2$ & $31.4 \pm 1.6$ & $36.2 \pm 1.4$ & $32.4 \pm 3.8$ & $35.4 \pm 1.4$ & $33.8 \pm 6.4$ & $38.8 \pm 6.6$ & $34.5 \pm 1.1$ \\
\hline
\end{tabular}

$\mathrm{IC}_{50}$ Inhibitory Concentration 50\% ( $\left.\mu \mathrm{M}\right)$

\section{Inoculation of Galleria mellonella larvae}

Ten larvae of G. mellonella (purchased at Animalis center) were stored in the dark at $15^{\circ} \mathrm{C}$. Larvae of the same age and weighing around $0.2 \mathrm{~g}$ were inoculated with $20 \mu \mathrm{L}$ of water containing $510^{7} \mathrm{~S}$. aureus cells through the last pro-leg using a Myjector U100 insulin syringe (Terumo Europe, Leuven, Belgium).

\section{In vivo toxicity assay}

Larvae were injected with $20 \mu \mathrm{L}$ of isonitrosomalononitrile silver salt 4 solution $(31.25,62.5,125,250,500$ or $1000 \mu \mathrm{M})$ or water. Larvae were incubated at $30^{\circ} \mathrm{C}$ for $24 \mathrm{~h}$ prior to quantifying survival.

\section{Effect of isonitrosomalononitrile silver salt 4 on survival of larvae infected with $S$. aureus}

Larvae were injected with $20 \mu \mathrm{L}$ of isonitrosomalononitrile silver salt 4 solution $(62.5 \mu \mathrm{M}) 4 \mathrm{~h}$ post-inoculation with $S$. aureus. The control consisted of larvae inoculated with $S$. aureus treated or not with water $(20 \mu \mathrm{L})$. Larvae were incubated at $30^{\circ} \mathrm{C}$ and survival was assessed at $24 \mathrm{~h}$.

\section{Determination of minimal inhibitory concentrations}

Antimicrobial activity of the compounds was studied by determination of minimal inhibitory concentrations (MIC) according to the NCCLS guidelines M7-A2 using the microbroth dilution methods. The bacteria strains were grown on trypticase soy agar (Becton Dickinson) at $37^{\circ} \mathrm{C}$ for $24 \mathrm{~h}$. Inocula were prepared in TCE (tryptone $0.1 \%, \mathrm{NaCl} 8 \%, \mathrm{wt} / \mathrm{vol}$ ) by adjusting the turbidity at $623 \mathrm{~nm}$ to obtain 1-3 $10^{5} \mathrm{CFU} / \mathrm{mL}$.

Antimicrobial activities of the compounds were determined by using a broth microdilution method performed in sterile 96well microplates. All compounds were solubilized in water at a concentration of $10 \mathrm{mM}$ and were transferred to each microplate well in order to obtain a two-fold serial dilution in $100 \mu \mathrm{L}$ of broth and $100 \mu \mathrm{L}$ of inoculum containing 2-6 $10^{5} \mathrm{CFU}$ of each bacterium were added to each well. Some wells were reserved for positive controls and inoculum viability. After $24 \mathrm{~h}$ incubation, MIC was defined for each agent from duplicate observations as the lowest concentration of compound allowing no visible growth.

\section{Cytotoxicity assays}

The cytotoxic activities of 4 were assessed on 5 cell lines provided from ATCC-LGC Standards Sarl (Molsheim, France): Chinese hamster Ovary cells (CHO-K1), Hepatocellular carcinoma cells (HepG2), Canine kidney cells (MDCK), primary mouse embryonic fibroblasts (3T3), and immortalized human keratinocytes (Hacat). Cells were maintained in Mc Coy's 5A (CHO) or DMEM (HEPG2, MDCK, 3T3, Hacat) media supplemented with $10 \%$ bovine calf serum, $2 \mathrm{mM}$ glutamine, and $100 \mathrm{U} \cdot \mathrm{mL}^{-1} / 10 \mu \mathrm{g} \cdot \mathrm{mL}^{-1}$ penicillin/streptomycin mixtures. For the cytotoxicity experiments, they were seeded in 96well plates and incubated at $37^{\circ} \mathrm{C}$ in humidified atmosphere containing $5 \% \mathrm{CO}_{2}$ overnight, and then concentrations of compounds were incorporated in triplicate cultures. After a 24-hours incubation period at $37^{\circ} \mathrm{C}$, cells were submitted to three successive washes in phosphate buffer saline (PBS) and cell viability was evaluated by two different vital dyes:

- A first set of cell cultures was incubated in PBS containing $10 \%$ WST- 1 for $30 \mathrm{~min}$ at $37^{\circ} \mathrm{C}, 5 \% \mathrm{CO}_{2}$. Cell viability was evaluated by the assessment of WST-1 absorbance at $450 \mathrm{~nm}$ in a microplate spectrophotometer.

A second set of cell cultures was placed into Neutral Red medium $(50 \mu \mathrm{g} / \mathrm{ml}$ Neutral Red in complete medium) and incubated for 3 hours at $37^{\circ} \mathrm{C}, 5 \% \mathrm{CO}_{2}$. Then the Neutral Red medium was removed and the distaining solution (50\% ethanol, $1 \%$ acetic acid, $49 \%$ distilled water; $50 \mu \mathrm{L}$ per well) was added into the wells. The plates were shaken for 15-20 min at room temperature in the dark. Cell viability was evaluated by the assessment of absorbance at $540 \mathrm{~nm}$ in a microplate spectrophotometer.

Results were expressed as percentages of cell viability about the control (culture medium-only), which corresponded to $100 \%$ cell viability. Dose-response curves were calculated by non-linear regression analysis with Table Curve V2 software. The Inhibitory Concentration $50 \%\left(\mathrm{IC}_{50}\right)$ was defined as the concentration of 4 that induced a $50 \%$ decrease of viable cells.

\section{Acknowledgments}

Chevreul Institute (FR 2638), Region Hauts-de-France, and FEDER are acknowledged for funding the X-ray diffractometers.

\section{References}

1. Schillaci D, Spanò V, Parrino B, Carbone A, Montalbano A, et al. (2017) Pharmaceutical Approaches to Target Antibiotic Resistance Mechanisms. J Med Chem 60: 8268-8297.

2. Clardy J, Fischbach MA, Walsh CT (2006) New antibiotics from bacterial natural products. Nat Biotechnol 24: 1541-1550.

3. Fernandes $P$ (2006) Antibacterial discovery and development--the failure of success? Nat Biotechnol 24: 1497-1503.

4. Rossiter SE, Fletcher MH, Wuest WM (2017) Natural Products as Platforms To Overcome Antibiotic Resistance. Chem Rev 117: 1241512474.

5. Alanis AJ (2005) Resistance to antibiotics: are we in the postantibiotic era? Arch Med Res 36: 697-705.

6. Foster TJ (2004) The Staphylococcus aureus "superbug". J Clin Invest 114: 1693-1696.

7. Rex JH (2014) ND4BB: addressing the antimicrobial resistance crisis. Nat Rev Microbiol 12: 231-232. 
8. Mijnendonckx K, Leys N, Mahillon J, Silver S, Van Houdt R (2013) Antimicrobial silver: uses, toxicity and potential for resistance. Biometals 26: 609-621.

9. Oehninger L, Rubbiani R, Ott I (2013) N-Heterocyclic carbene metal complexes in medicinal chemistry. Dalton Trans 42: 3269-3284.

10. Liang X, Luan S, Yin Z, He M, He C, et al. (2018) Recent advances in the medical use of silver complex. Eur J Med Chem 157: 62-80.

11. Jaros SW, Guedes da Silva MF, Florek M, Smoleński P, Pombeiro AJ, et al. (2016) Silver(I) 1,3,5-Triaza-7-phosphaadamantane Coordination Polymers Driven by Substituted Glutarate and Malonate Building Blocks: Self-Assembly Synthesis, Structural Features, and Antimicrobial Properties. Inorg Chem 55: 5886-5894.

12. Jaros SW, Smoleński P, Guedes da Silva MFC, Florek M, Król J, et al. (2013) New silver BioMOFs driven by 1,3,5-triaza-7phosphaadamantane-7-sulfide (PTA[double bond, length as m-dash]S): synthesis, topological analysis and antimicrobial activity. Cryst Eng Comm 15: 8060-8064.

13. Smoleński P, Jaros SW, Pettinari C, Lupidi G, Quassinti L, et al. (2013) New water-soluble polypyridine silver(i) derivatives of 1,3,5-triaza7-phosphaadamantane (PTA) with significant antimicrobial and antiproliferative activities. Dalton Trans 42: 6572-6581.

14. Thurman RB, Gerba CP (1989) The molecular mechanisms of copper and silver ion disinfection of bacteria and viruses. Crit Rev Environ Control 18: 295-315.

15. Adams AP, Santschi EM, Mellencamp MA (1999) Antibacterial properties of a silver chloride-coated nylon wound dressing. Vet Surg 28: 219-225.

16. Percival SL, Bowler PG, Russell D (2005) Bacterial resistance to silver in wound care. J Hosp Infect 60: 1-7.

17. Kascatan-Nebioglu A, Melaiye A, Hindi K, Durmus S, Panzner MJ, et al. (2006) Synthesis from caffeine of a mixed $\mathrm{N}$-heterocyclic carbene-silver acetate complex active against resistant respiratory pathogens. J Med Chem 49: 6811-6818.

18. Hindi KM, Siciliano TJ, Durmus S, Panzner MJ, Medvetz DA, et al. (2008) Synthesis, stability, and antimicrobial studies of electronically tuned silver acetate N-heterocyclic carbenes. J Med Chem 51: 15771583.
19. Hackenberg F, Tacke M (2014) Benzyl-substituted metallocarbene antibiotics and anticancer drugs. Dalton Trans 43: 8144-8153.

20. Patil S, Deally A, Gleeson B, Müller-Bunz H, Paradisi F (2011) Novel benzyl-substituted $\mathrm{N}$-heterocyclic carbene-silver acetate complexes: synthesis, cytotoxicity and antibacterial studies. Metallomics 3: 7488.

21. Palatinus L, Chapuis G (2007) G SUPERFLIP-a computer program for the solution of crystal structures by charge flipping in arbitrary dimensions. J Appl Crystallogy 40: 786-790.

22. Petříček V, Dušek $M$, Palatinus L (2014) Crystallographic Computing System JANA2006: General features. Z Kristallogr Cryst Mater 229: 345-352.

23. Ali B, Belkhiria M, Giorgi M, Nasri H (2011) Synthesis, structural and spectroscopic characterization of the bis(nitrito-N) octaethylporphyrin cobalt(III) complex. Open J Inorg Chem 1: 39-46.

24. Kavanagh K, Reeves EP (2004) Exploiting the potential of Insects for in vivo pathogenicity testing of Microbial pathogens. FEMS Microbiol Rev 28: 101-112.

25. Desbois AP, Coote PJ (2012) Utility of greater wax moth larva (Galleria mellonella) for evaluating the toxicity and efficacy of new antimicrobial agents. Adv App Microbiol 78: 25-53.

26. Kelly J, Kavanagh K (2011) Caspofungin primes the immune response of the larvae of Galleria mellonella and induces a non-specific antimicrobial response. J Med Microbiol 60: 189-196.

27. Fuchs BB, Mylonakis E (2006) Using non-mammalian host to study fungal virulence and host defense. Curr Opin Microbiol 9: 346-351.

28. Hamamoto H, Kurokawa K, Kaito C, Kamura K, Manitra Razanajatovo I, et al. (2004) Quantitative evaluation of the therapeutic effects of antibiotics using silkworms infected with human pathogenic microorganisms Antimicrob Agents Chemother 48: 774-779.

29. Lionakis MS, Kontoyiannis DP (2005) Fruit flies as a mini-host model for studying drug activity and virulence in Aspergillus. Med Mycol 43: 111-114. 